\title{
Effect of Different Saw Dust Substrates on the Nutritional Composition of Oyster Mushroom (Pleurotus florida) and its Applications in Human Health
}

\author{
Ratan Kumar Paul ${ }^{1,6}$, Debu Kumar Bhattacharjya ${ }^{2}$, Abul Kalam Lutful Kabir ${ }^{3}$, \\ Md. Harun-or-Rashid ${ }^{2}$, Md. Samsur Rahaman ${ }^{4}$, Md. Saifur Rahaman ${ }^{5}$, \\ Md. Nuruddin Miah ${ }^{2}$ and Kamal Uddin Ahmed ${ }^{2}$
}

\author{
${ }^{1}$ Department of Chemistry, Pabna University of Science and Technology (PUST), Pabna-6600, Bangladesh \\ ${ }^{2}$ Department of Biochemistry, Sher-e-Bangla Agricultural University, Dhaka, Bangladesh \\ ${ }^{3}$ Department of Pharmaceutical Technology, University of Dhaka, Dhaka-1000, Bangladesh \\ ${ }^{4}$ Department of Applied Chemistry, Islamic University, Kushtia - Jhenaidah -7003, Bangladesh \\ ${ }^{5}$ Institute of Radiation and Polymer Technology, Atomic Energy Research Establishment, Bangladesh Atomic \\ Energy Commission, Dhaka, PO. Box 3787, Bangladesh \\ ${ }^{6}$ Department of Chemistry, Bangladesh University of Engineering and Technology (BUET), \\ Dhaka-1000, Bangladesh
}

Received: November 30, 2015; Accepted: January 28, 2016; Published (web): January 31, 2016

\begin{abstract}
This study evaluated the effects of various sawdust substrates, namely Ficus carica (Fig tree, $\mathbf{T}_{2}$ ), Albizia saman (Rain Tree, $\mathbf{T}_{\mathbf{3}}$ ), Swietenia mahagoni (Mahogany tree, $\mathbf{T}_{4}$ ), Leucaena leucocephala (Ipil ipil tree, $\mathbf{T}_{5}$ ), Eucalyptus oblique (Indian gum tree, $\mathbf{T}_{6}$ ) and mixture of mentioned five trees sawdust $\left(\mathbf{T}_{1}\right)$ supplemented with $30 \%$ wheat bran and $1 \%$ lime on the mineral content and nutritional composition analyses of Plurotus florida mushroom. The highest amount of carbohydrate $(43.68 \mathrm{mg} / 100 \mathrm{~g})$, dry matter $(9.87 \%)$, nitrogen $(4.43 \%)$, potassium $(1.39 \%)$, magnesium $(19.96 \mathrm{mg} / 100 \mathrm{~g})$ and iron $(44.69 \mathrm{mg} / 100 \mathrm{~g})$ were obtained from $\mathbf{T}_{\mathbf{4}}$ sawdust substrate. The highest amount of phosphorous $(0.89 \%)$ was obtained from $\mathbf{T}_{\mathbf{1}}$ substrate. The highest amount of lipid (4.21\%), protein (27.68\%), ash (13.67\%), moisture (90.27\%) and molybdenum $(9.76 \mathrm{mg} / 100 \mathrm{~g})$ were obtained from $\mathbf{T}_{2}$ sawdust substrate. The lowest amount of lipid (3.42\%) was found for $\mathbf{T}_{\mathbf{6}}$ substrate. The highest amount of crude fiber (19.78\%), calcium $(33.35 \mathrm{mg} / 100 \mathrm{~g})$ and selenium $(9.10 \mathrm{mg} / 100 \mathrm{~g})$ were obtained from $\mathbf{T}_{\mathbf{5}}$ substrate. The highest amount of cobalt $(21.07 \mathrm{mg} / 100 \mathrm{~g})$ and zinc $(30.26 \mathrm{mg} / 100 \mathrm{~g})$ were obtained from $\mathbf{T}_{3}$ sawdust substrate. Thus, they could be an excellent source of many different nutraceuticals and might be used directly in human diet to promote health for the synergistic effects of all the bioactive compounds present. The study proved beneficial for effective management of agricultural wastes as well as production of nutraceutical effective fruiting bodies for balanced diet.
\end{abstract}

Key words: Pleurotus florida, nutrition; proximate analysis, mineral content, saw dust, Wheat Bran

\section{INTRODUCTION}

Oyster mushrooms are edible fungi and belong to the genus Pleurotus, class-Basidiomycetes, orderAgaricales and family-Pleurotaceae. ${ }^{1,2}$ For the excellent flavor and taste Pleurotus species are delicacies in different parts of the world. ${ }^{3-7}$ Cultivation of the mushroom can create working area

Correspondence to: Ratan Kumar Paul

Tel: 073164921 (Office); Mobile: +8801714704579

E-mail: ratanpaul05@yahoo.com; ratanpaul05@pust.ac.bd

Dhaka Univ. J. Pharm. Sci. 14(2): 215-223, 2015 (December) and eradicate unemployment problem by creating employment opportunity in urban and rural areas. ${ }^{8}$ These mushrooms can also ensure the availability of it at low price and for recycling of agricultural wastage. $^{9-11}$

Since time immemorial mushrooms are being used as food and medicine to promote good health and vitality and increasing body's adaptive abilities. ${ }^{12}$ More than 100 medicinal functions are produced by mushrooms and the key medicinal uses are 
antioxidant, anticancer, antidiabetic, immunomodulating, cardiovascular protector, antiviral, antibacterial, antiparasitic, detoxification and hepatoprotective effects; they also protect against tumor development and inflammatory processes. ${ }^{13-17}$ Numerous molecules synthesized by mushrooms are known to be bioactive, and these bioactive compounds found in fruit bodies, cultured mycelium, and cultured broth are polysaccharides, proteins, fats, minerals, glycosides, alkaloids, terpenoids, tocopherols, phenolics, flavonoids, carotenoids, lectins, enzymes, ascorbic, and organic acids, in general. Polysaccharides are the most important for modern medicine and $\beta$-glucan is the best known and the most versatile metabolites with a wide spectrum of biological activities. ${ }^{13,15,18,19,22}$ They have also a great nutritional value since they are quite rich in protein, with an important content of essential amino acids and fiber, poor fat but with excellent important fatty acids content. Moreover, edible mushrooms provide a nutritionally significant content of vitamins $\left(\mathrm{B}_{1}, \mathrm{~B}_{2}, \mathrm{~B}_{12}, \mathrm{C}, \mathrm{D}\right.$, and $\left.\mathrm{E}\right){ }^{20,21}$ It is important to note that all Pleurotus species are consumable. ${ }^{7,14,23-27}$

Oyster mushrooms are commercial mushrooms that are least expensive and easiest to grow because they are well known for conversion of crop residues to food protein. ${ }^{28}$ A number of studies on cultivation of them on solid substrates such as sawdust and different agricultural wastes such as rice bran, wheat bran, sugarcane bagasse, rice husks, coconut fiber, peanut hulls, and banana leaves etc. ${ }^{29-32}$ to improve the production, quality, flavor, and shelf life of cultivated mushrooms have been reported. ${ }^{33-35}$

Sawdust, a by-product of the saw-mill industries, is largely available and has been considered a possible alternative for mushroom cultivation. Additional nitrogen, phosphate and potassium are required for the cultivation of mushrooms with sawdust as the ligno-cellulosic materials in sawdust are generally low in protein content and thus insufficient for the cultivation of mushrooms. Prior to spawning for enhancement of the yield of mushrooms supplementation of the substrate with various materials is thus recommended. ${ }^{36}$ The use of wheat and other cereal bran, as supplements, has gained importance in the cultivation of mushrooms. Wheat bran is rich in protein $(\sim 14 \%)$, carbohydrates $(\sim 27 \%)$, minerals $(\sim 5 \%)$, fat $(\sim 6 \%)$ and $\mathrm{B}$ vitamins. ${ }^{37}$

For this potential and nutritive edible item, works on the nutritive analysis are not available in Bangladesh and there is no mushroom based balanced diet charts for the common people as well as for the patient. For this reason the proximate analysis for the oyster mushroom (Pleurotus florida) is necessary. This is also important to find out the nutritional status of mushroom growing in different substrates, which will help to select mushrooms as a food in balanced diet. Therefore, the objective of this work is to find out the suitable saw dust with substrate for proximate analysis and determination of mineral contents of oyster mushroom (Pleurotus florida).

\section{MATERIALS AND METHODS}

Experimental location and materials. The experiment was carried out jointly at the Mushroom Culture House $(\mathrm{MCH})$, Biochemistry laboratory of the Department of Biochemistry, Sher-e-Bangla Agricultural University, Dhaka, Bangladesh and Material Chemistry laboratory of Department of Chemistry, BUET, Dhaka-1000, Bangladesh. Fruiting body of Pleurotus florida was collected from National Mushroom Development and Extension Center (NAMDEC), Saver, Dhaka, Bangladesh. Pleurotus florida was grown on different saw dust supplemented with $30 \%$ wheat bran and $1 \%$ lime on the spawn packet. All the chemicals used were collected from Merck (Germany), Wako Pure Chemicals Industries Ltd. and JHD (China). The sample was weighted by electric balance (KEY: JY2003; China) and heated in a muffle furnace (Nebertherm: Mod-L9/11/c6; Germany). The amount of minerals were determined by atomic absorption spectrophotometer (analytikjenanov AA 400P; Germany), flame photometry (PFP7; Germany), and spectrophotometer (HALO BD-20S; Germany).

Cultivation and harvesting of Pleurotus florida mushroom. Five different saw dust substrates 
namely, fig tree (Ficus carica, $\mathbf{T}_{2}$ ), rain tree (Albiziasaman, $\mathbf{T}_{\mathbf{3}}$ ), mahogany tree (Swietenia mahagoni, $\mathbf{T}_{\mathbf{4}}$ ), ipil ipil tree (Leucaenaleucocephala, $\mathbf{T}_{5}$ ), Indian gum tree (Eucalyptus obliqua, $\mathbf{T}_{\mathbf{6}}$ ) and a control ( $\left.\mathbf{T}_{1}\right)$ supplemented with $30 \%$ wheat bran and $1 \%$ lime were used throughout the present study. Sterilization, cultivation, and harvesting of the oyster mushroom (Pleurotus florida) were performed on spawn packets following literature. ${ }^{38-40}$ Then the harvested mushroom samples were subjected to proximate and mineral content analyses.

Proximate analysis. Mushrooms grown from the spawn were collected from each packet separately and all the wastes and dusts were removed from the fruiting body. Thereafter, they were ready to analyze.

Estimation of moisture. About $10-20 \mathrm{~g}$ of the material of each sample were weighed separately and then the samples were dried in an oven at $105{ }^{\circ} \mathrm{C}$ with pre-weighed petridishes till the weight of the petridishes with their contents were constant. The moisture content was expressed by percent and evaluated by the formula described by Raghuramulu et al., 2003 and Sarker et al., 2007..$^{41,42}$

Estimation dry matter. A clean container (dish or beaker) was place in an oven at $105{ }^{\circ} \mathrm{C}$ overnight. The container was allowed to cool in a desiccator and was weighted. The samples were kept into the container and the samples were weighted. The container was placed in the oven at $105{ }^{\circ} \mathrm{C}$ for $24 \mathrm{~h}$ again. The container was allowed to cool in a desiccator and was weighted. Again, the container was placed in the oven at $105{ }^{\circ} \mathrm{C}$ for $2 \mathrm{~h}$. It was cooled in a desiccator and weighted again. Repeat drying, cooling and weighing was continued until the weight becomes constant. Then the percentage of dry matter content of the sample was evaluated by the formula found elsewhere. ${ }^{41,42}$

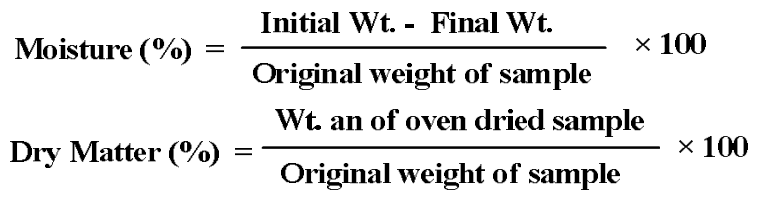

Estimation of crude fiber. Ten grams of moisture and fat-free sample was taken in a beaker and was added $200 \mathrm{ml}$ of boiling $0.255 \mathrm{~N} \mathrm{H}_{2} \mathrm{SO}_{4}$. The mixture was boiled for $30 \mathrm{~min}$ to keep the volume constant by the addition of water at frequent intervals. The mixture was then filtered through a muslin cloth and the residue washed with hot water till free from acid. The material was then transferred to the same beaker, and $200 \mathrm{ml}$ of boiling $0.313 \mathrm{~N}$ $\mathrm{NaOH}$ added. After boiling for 30 min (keeping the volume constant as before) the mixture was filtered through a muslin cloth and the residue washed with hot water till free from alkali followed by washing with some alcohol and ether. It was then transferred to a crucible, dried overnight at $80-100{ }^{\circ} \mathrm{C}$ and weighed. The crucible was heated in a muffle furnace at $600{ }^{\circ} \mathrm{C}$ for $5-6 \mathrm{~h}$, cooled and weighed again. The difference of those two mentioned weights represents the weight of crude fiber and percentage was calculated by the formula found in the literature. ${ }^{41,43}$

Crude Fiber $(\%)=\frac{\text { Dry weight after digestion }\left(W_{e}\right)-\text { Weight of ash }\left(W_{\mathrm{a}}\right)}{\text { weight of moisture and fat-free fat-free sample }} \times 100$

Estimation of lipid. Fat was estimated by crude ether extraction of the dry materials. The dried samples (about $5 \mathrm{~g}$ ) were weighted into a conical flask and plugged with fat free cotton. The flask was then placed in an electric shaker and extracted with anhydrous ether for about $16 \mathrm{~h}$. The ether extract was filtered into another weighed conical flask. The flask containing the original ether extract was washed 4 to 5 times with small quantities of ether and the washings were also transferred to the filter paper. The ether in the conical flask was then removed by evaporation, and the flask with the residual was dried in an oven at $80{ }^{\circ} \mathrm{C}$ to $100{ }^{\circ} \mathrm{C}$, cooled in a desiccator and weighted as well as percentage of lipid was determined by the formula found elsewhere. ${ }^{41}$ 


\section{Fat Contents $(\mathrm{g})$ per $100 \mathrm{~g}$ of Dried Sample $=$ Weight of Ether Extract $\times$ Percentage of Dried Sample \\ Weight of Dried Sample Taken}

Estimation of total carbohydrate: Carbohydrate content was determined and expressed by percentage by the formula found in the literature. ${ }^{41,44}$

\section{Carbohydrate (g/100g sample) $=100-[($ Moisture+Fat+Protein+Ash+Crude Fiber) $\mathrm{g} / 100 \mathrm{~g}]$}

Estimation of total ash: Ash content of the samples was determined by heating the pre dried samples in a muffle furnace for about 5-6 h at $600{ }^{\circ} \mathrm{C}$ until stable weight is gained and white or grayish white color is obtained. Percentage of ash also calculated by the formula found elsewhere. ${ }^{41}$

\section{Ash content $(\mathrm{g} / \mathrm{l00g}$ sample $)=\mathrm{Wt}$ of $\operatorname{ash} \times 100 / \mathrm{Wt}$ of sample taken}

Estimation of crude protein: Sample was dried and grinded using a mortar and pestle to analyze crude protein content. James (1995) and Chang \& Buswell (2003) described the Kjeldahl method in which the nitrogen 'content was first determined and then multiplied with 6.25 to obtain the protein content of the sample. ${ }^{45,46}$ Then the percentages of protein were calculated by using the formula.

\section{Crude protein $(\%)=\% \mathrm{~N} \times \mathbf{6 . 2 5}$}

Mineral content estimation: Total nitrogen was determined by a micro kjaldhal apparatus in the traditional method and calculated using the following formula.

$$
\% \mathrm{~N} \text { in the supplied fiber sample }=\frac{\left(\mathrm{a} \times \mathrm{M}_{\mathrm{IICl}}-\mathrm{b} \times \mathrm{M}_{\mathrm{NaOH}}\right) \times 1.401}{c}
$$

Where,

$$
\begin{aligned}
& \mathrm{a}=\mathrm{ml} \mathrm{HCI} \text { measured into the conical flask in the distill } \mathrm{H}_{2} \mathrm{O} \text { (usually } 20.00 \mathrm{ml} \text { ) } \\
& \mathrm{b}=\mathrm{ml} \mathrm{NaOH} \text { used for titration of the content in the conical flask } \\
& \mathrm{c}=\mathrm{g} \text { powder of sample used for the analysis } \\
& \mathrm{M}_{\mathrm{HCl}}=\text { molarity of the } \mathrm{HCI} \text { measured into the conical flask } \\
& \mathrm{M}_{\mathrm{NaOH}}=\text { molarity of the } \mathrm{NaOH} \text { used for titration }
\end{aligned}
$$

The sample were digested with nitric acid to release of $\mathrm{Ca}, \mathrm{Mg}, \mathrm{K}, \mathrm{Fe}$, and $\mathrm{P}, \mathrm{Ca}, \mathrm{Mg}, \mathrm{Fe}$, were determined by atomic absorption spectrophotometer, $\mathrm{K}$ was determined by flame photometry, and $\mathrm{P}$ was determined by spectrophotometer using the formula found in the literature. ${ }^{47}$

$\mathrm{Fe}, \mathrm{Mo}, \mathrm{Zn}, \mathrm{Co}$ and Se contents were also measured by atomic absorption spectrometer (AAS) directly in the undiluted filtrate by using the formula found in the literature. ${ }^{22,47}$

For Ca, Mg, K and P mg per kg sample $=\frac{a \times 25000}{b \times c}$
Where,

$\mathrm{a}=\mathrm{mg} / \mathrm{L} \mathrm{Ca}, \mathrm{Mg}, \mathrm{K}$ or $\mathrm{P}$ measured on atomic absorption spectrometer, flame photometer

$\mathrm{b}=\mathrm{ml}$ diluted filtrate transferred into the $50 \mathrm{ml}$ volumetric flask for determination of $\mathrm{Ca}, \mathrm{Mg}, \mathrm{K}$ and $\mathrm{P}$

$\mathrm{c}=\mathrm{g}$ sample weighed into the digestion tube

For Fe, Mo, Zn, Co and Se mg per kg sample $=\frac{d \times 100}{c}$

Where, $\mathrm{d}=\mathrm{mg} / \mathrm{L} \mathrm{Fe}$, measured on atomic absorption spectrophotometer $\mathrm{c}=\mathrm{g}$ sample weighed into the digestion tub 
Statistical analysis of data. Data on various parameters were analyzed by following standard statistical method utilizing Microsoft Office Excel 2013. These dates were analyzed by considering 5 treatments with 3 replications and 1 spawn packets in each replication. The data for the characters considered in the present experiments were statistically analyzed by the complete randomized design (CRD) and randomized complete block design (RCBD) method. The analysis of variance was conducted and means were compared following least significant difference (LSD) test at $1 \%$ and 5\% level of probability for interpretation of results were the formula found in the literature. ${ }^{48}$

\section{RESULTS AND DISCUSSION}

Proximate composition of Pleurotus florida. All the treatments were statistically similar but varied numerically with each other as shown in table1. The amount of moisture content ranged from 90.27 to 90.13\% was found. The highest moisture content (90.27\%) was observed under $\mathbf{T}_{\mathbf{2}}$ followed by $\mathbf{T}_{\mathbf{6}}$. However, the lowest moisture $(90.13 \%)$ was in observed under $\mathbf{T}_{\mathbf{4}}$ treatment (Table 1). The results of the present study are supported by other such studies as Moni et al. (2004) found 88.15 to $91.64 \%$ moisture content. Alam et al. (2007) reported 87 to $87.5 \%$ moisture content for oyster mushrooms grown on different substrates ${ }^{49,22}$

The amount of dry matter of fruiting body was found in 9.87 to $9.73 \%$ ranges. The highest amount of dry matter $(9.87 \%)$ was observed under $\mathbf{T}_{\mathbf{4}}$ followed by $\mathbf{T}_{\mathbf{1}}$ and $\mathbf{T}_{\mathbf{5}}$. The lowest amount of dry matter $(9.73 \%)$ was observed under $\mathbf{T}_{\mathbf{2}}$ as shown in table 1 . The result of the present study matches the findings of Ahmed et al. (2013). ${ }^{44}$ They found dry matter of fruiting bodies ranged from 9.40-9.98\% when sawdust supplemented with cow dung.

The protein content varied from 27.68 to 25.06 $\%$. The highest amount of protein $(27.68 \%)$ was found from $\mathbf{T}_{2}$ and the lowest amount of protein content $(25.06 \%)$ was found from $\mathbf{T}_{\mathbf{3}}$ (Table 1 ). The result of Chang et al. (1981) corroborates the results of this present study. ${ }^{50}$ They reported that the fruit bodies of oyster mushrooms contained 26.6-34.1\% protein. Similar result was also reported by ZhangRui Hong et al. (1998). ${ }^{51}$

The lowest amount of lipid (3.42\%) was counted under $\mathbf{T}_{\mathbf{6}}$ followed by $\mathbf{T}_{\mathbf{1}}$ and the highest lipid $(4.21 \%)$ amount was calculated under $\mathbf{T}_{\mathbf{3}}$ as shown in table 1. The result of the present study was significantly varied with the findings of Chang et al. (1981) who found 1.1-8.0 \% ${ }^{50}$ However this present study results well fits with the results reported by Alam et al. (2007), who reported 4.30-4.41\% lipids in oyster mushroom grown on different substrates. ${ }^{22}$

The highest amount of crude fiber (19.78\%) was found from $\mathbf{T}_{5}$ followed by $\mathbf{T}_{3}$ and the lowest crude fiber (16.92\%) amount was counted under $\mathbf{T}_{\mathbf{4}}$ as shown in table 1 . The findings are corroborated by the study of Alam et al., (2007), who reported 8.7 $\mathrm{g} / 100 \mathrm{~g}$ to $23.29 \mathrm{~g} / 100 \mathrm{~g}$ of fiber in Pleurotus spp. ${ }^{22}$

Table 1. Effect of sawdust substrates on chemical composition of Pleurotus florida.

\begin{tabular}{|c|c|c|c|c|c|c|c|}
\hline Treatments & $\begin{array}{c}\text { Moisture } \\
(\%)\end{array}$ & $\begin{array}{c}\text { Dry matter } \\
(\%)\end{array}$ & $\begin{array}{c}\text { Protein } \\
(\%)\end{array}$ & $\begin{array}{c}\text { Lipid } \\
(\%)\end{array}$ & $\begin{array}{l}\text { Ash } \\
(\%)\end{array}$ & $\begin{array}{c}\mathrm{CHO} \\
(\%)\end{array}$ & $\begin{array}{c}\text { Crude fiber } \\
(\%)\end{array}$ \\
\hline $\mathrm{T}_{1}$ & $90.17 b$ & $9.83 a$ & $26.61 \mathrm{ab}$ & $3.43 d$ & $12.33 \mathrm{ab}$ & $39.86 b c$ & $17.79 \mathrm{ab}$ \\
\hline $\mathrm{T}_{2}$ & $90.27 \mathrm{a}$ & $9.73 c$ & $27.68 \mathrm{a}$ & $4.07 \mathrm{a}$ & $13.67 \mathrm{a}$ & $37.20 \mathrm{c}$ & $17.42 b$ \\
\hline $\mathrm{T}_{3}$ & $90.20 \mathrm{~b}$ & $9.80 \mathrm{~b}$ & $25.06 \mathrm{c}$ & $4.21 \mathrm{a}$ & $9.33 c$ & $41.68 \mathrm{ab}$ & $19.72 \mathrm{a}$ \\
\hline $\mathrm{T}_{4}$ & $90.13 c$ & $9.87 \mathrm{a}$ & $25.89 b c$ & $3.85 \mathrm{bc}$ & $9.67 \mathrm{c}$ & $43.68 \mathrm{a}$ & $16.92 \mathrm{c}$ \\
\hline $\mathrm{T}_{5}$ & $90.17 b$ & $9.83 \mathrm{a}$ & $25.81 b c$ & $3.64 \mathrm{~cd}$ & $10.00 \mathrm{c}$ & $40.68 \mathrm{ab}$ & $19.78 \mathrm{a}$ \\
\hline $\mathrm{T}_{6}$ & $90.23 \mathrm{a}$ & $9.77 b$ & $26.09 b$ & $3.42 \mathrm{~d}$ & $10.67 b c$ & $40.13 b c$ & $19.70 \mathrm{a}$ \\
\hline $\mathrm{CV}(\%)$ & $0.1 \%$ & $5.98 \%$ & $12.75 \%$ & $4.48 \%$ & $8.77 \%$ & $2.48 \%$ & $1.53 \%$ \\
\hline $\operatorname{LSD}_{(0.05)}$ & 0.20 & 0.84 & 4.31 & 0.30 & 1.75 & 1.30 & 0.89 \\
\hline
\end{tabular}

Means followed by same letter significantly different at $1 \%$ or $5 \%$ level of significance.

Different saw dust substrates and wheat bran had an effect on the approximate composition of pleurotus florida which was shown in figure 1. 


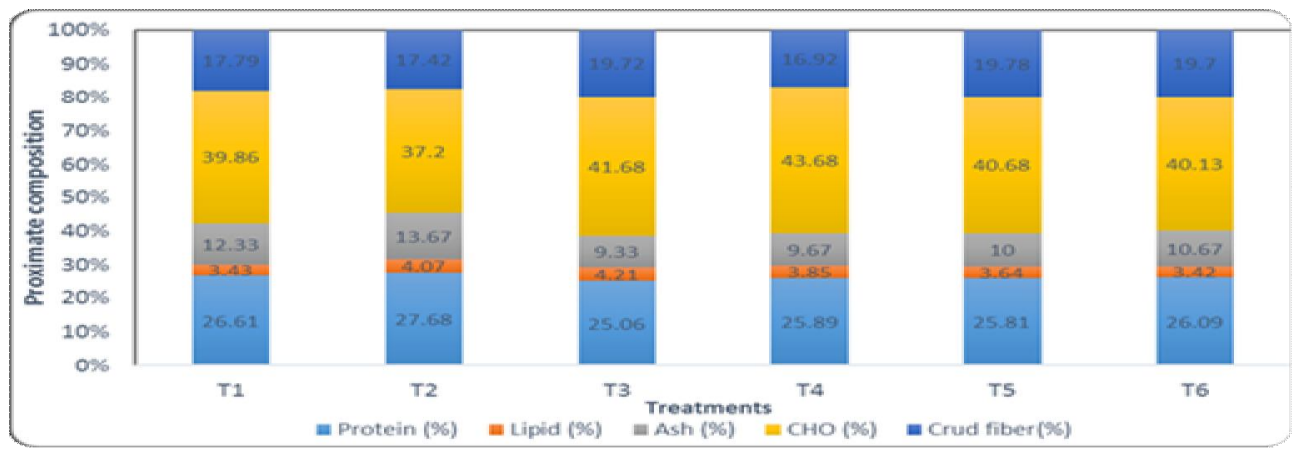

Figure 1. Effect of saw dust substrates with wheat bran on the proximate composition analysis of dry matter of Pleurotus florida.

The lowest amount of carbohydrate (37.20) was counted under $\mathbf{T}_{\mathbf{2}}$ and the highest carbohydrate content (43.68) was found from $\mathbf{T}_{\mathbf{4}}$ (Table 1). The findings of the present study does not match with the study of Chang et al. (1981) reported that the fruit bodies mushrooms contained $40.30-50.7 \%$ of carbohydrates ${ }^{50}$. But it was supported by Alam et al. (2007) who found 39.82 to $42.83 \%$ of carbohydrates in Pleurotus spp. ${ }^{22}$

The highest ash content (13.67) was observed under $\mathbf{T}_{\mathbf{2}}$ and the lowest amount of ash (9.33) was observed under $\mathbf{T}_{\mathbf{3}}$ (Table 1). The findings are supported by the study of Khlood et al.. 2005, who reported the ash contents to be moderate in the fruiting bodies. ${ }^{52}$ Alam et al., 2007 reported 8.28 to $9.02 \%$ of ash in Pleurotus spp. ${ }^{22}$ In the present study the ash content is as high as 13.67 may be due to the newly introduced varieties. ${ }^{44}$

Mineral contents of Pleuurotus florida. Table 2 shows the mineral contents found from the harvested mushrooms grown under different substrate treatment along with the supplements. The highest percentage of nitrogen (4.38) was found from $\mathbf{T}_{\mathbf{4}}$ followed by $\mathbf{T}_{\mathbf{2}}$ (4.38) and the lowest percentage of nitrogen (4.09) was counted under $\mathbf{T}_{\mathbf{3}}$ as shown in table 2 . Moni et al., 2004 who analyzed for various nutritional parameters and found 4.22 to $5.59 \%$ of nitrogen on dry matter basis in fruiting bodies of oyster mushroom that supports our findings. ${ }^{49}$

The highest percentage of phosphorus (0.89) was observed under $\mathbf{T}_{\mathbf{1}}$ and the lowest percentage of phosphorus (0.83) was counted under $\mathbf{T}_{\mathbf{3}}$ as shown in table 2. The finding does not match with the study of Chang et al., 1981. ${ }^{50}$ This may be due to the system of measurement. But Sarker et al., 2007 found 0.97\% phosphorus, in oyster mushroom grown on sawdust based substrates and which supports our findings. ${ }^{42}$

Potassium percentage was found highest from $\mathbf{T}_{\mathbf{4}}$ (1.39) and the lowest percentage of potassium were counted under $\mathbf{T}_{\mathbf{1}}$ and $\mathbf{T}_{\mathbf{6}}$ (1.17) as shown in table 2 . The finding of the present study conforms to that reported by Chang et al., $1981{ }^{50}$. They reported that the fruiting bodies of Pleurotus contained 1.432 to $1.88 \mathrm{mg} / \mathrm{g}$ of $\mathrm{K}$ on dry weigh of fruiting bodies. Sarker et al., 2007 also found 1.3\% potassium, in oyster mushroom grown on sawdust based substrates. ${ }^{42}$

Calcium percentage was observed highest under $\mathbf{T}_{5}$ (33.35) and the lowest percentage of calcium was counted under $\mathbf{T}_{\mathbf{2}}$ (27.66) as shown in table 2. The findings fit with the study of Alam et al. (2007) who found 22.15 to $33.7 \mathrm{mg} / 100 \mathrm{~g}$ of calcium in different oyster mushroom varieties. $^{22}$

The highest percentage of magnesium (19.96) was evaluated under $\mathbf{T}_{\mathbf{4}}$ and the lowest percentage of magnesium were counted under $\mathbf{T}_{\mathbf{2}}$ (13.68) (Table 2). The result reported by Alam et al. (2007) supports our findings, who found 13.4 to $20.22 \mathrm{mg} / 100 \mathrm{~g}$ of magnesium in different oyster mushroom varieties. ${ }^{22}$

The highest percentage of iron (44.69) was estimated under $\mathbf{T}_{\mathbf{4}}$ and the lowest percentage of iron (40.71) was counted under $\mathbf{T}_{\mathbf{3}}$ as shown in table 2 . Alam et al. (2007) reported similar result supporting our result. ${ }^{22}$ They found 33.45 to $43.2 \mathrm{mg} / 100 \mathrm{~g}$ of 
iron in different oyster mushroom varieties. Sarker $e t$ al. (2007) found $92.09 \mathrm{ppm}$ to $118.40 \mathrm{ppm}$ iron, in oyster mushroom grown on sawdust based substrates. ${ }^{42}$

The highest amount (mg) of zinc (30.26 $\mathrm{mg} / 100 \mathrm{~g}$ ) was counted under $\mathbf{T}_{\mathbf{3}}$ and the lowest amount $(18.70 \mathrm{mg} / 100 \mathrm{~g})$ was of zinc counted under $\mathbf{T}_{5}$ as shown in table 2 . The result of the present study matches with the study of Alam et al. (2007) found 16 to $20.9 \mathrm{mg} / 100 \mathrm{~g}$ of zinc in different oyster mushroom varieties. ${ }^{22}$ Sarker et al. (2007) found
$30.92 \mathrm{ppm}$ zinc, in oyster mushroom grown on sawdust based substrates. ${ }^{42}$

The highest amount of cobalt (21.07) was found from $\mathbf{T}_{\mathbf{3}}$ and the lowest amount of cobalt (9.30) was counted under $\mathbf{T}_{\mathbf{4}}$ (Table 2). The highest percentage of molybdenum (13.10) was counted under $\mathbf{T}_{1}$ and for the lowest percentage of molybdenum (4.27) was counted under $\mathbf{T}_{\mathbf{6}}$ (Table 2). Percentage of selenium was counted highest under $\mathbf{T}_{\mathbf{5}}(9.10)$ and lowest percentage of selenium was counted under $\mathbf{T}_{\mathbf{1}}$ (1.77) as shown in table 2 .

Table 2. Effect of sawdust substrates on mineral contents of Pleurotus florida.

\begin{tabular}{|c|c|c|c|c|c|c|c|c|c|c|}
\hline Treatments & $\mathrm{N}(\%)$ & $\mathrm{P}(\%)$ & $\mathrm{K}(\%)$ & $\mathrm{Ca}(\%)$ & $\operatorname{Mg}(\%)$ & $\begin{array}{c}\mathrm{Fe}(\%) \\
\mathrm{mg}\end{array}$ & $\begin{array}{c}\mathrm{Zn}(\%) \\
\mathrm{mg}\end{array}$ & $\begin{array}{c}\mathrm{Co}(\%) \\
\mathrm{mg}\end{array}$ & $\begin{array}{c}\mathrm{Mo}(\%) \\
\mathrm{mg}\end{array}$ & $\begin{array}{c}\text { Se }(\%) \\
\mathrm{mg}\end{array}$ \\
\hline $\mathrm{T}_{1}$ & $4.29 \mathrm{ab}$ & $0.89 \mathrm{a}$ & $1.17 \mathrm{c}$ & $30.38 \mathrm{ab}$ & $14.70 \mathrm{bc}$ & $41.57 b$ & $27.97 \mathrm{ab}$ & $12.10 \mathrm{bc}$ & $13.10 \mathrm{a}$ & $1.77 \mathrm{e}$ \\
\hline $\mathrm{T}_{2}$ & $4.38 \mathrm{a}$ & $0.86 \mathrm{ab}$ & $1.24 \mathrm{bc}$ & $27.66 \mathrm{~b}$ & $13.68 \mathrm{c}$ & $42.28 b$ & $27.86 \mathrm{~b}$ & $13.90 \mathrm{bc}$ & $9.76 \mathrm{ab}$ & $7.27 \mathrm{ab}$ \\
\hline $\mathrm{T}_{3}$ & $4.09 \mathrm{c}$ & $0.83 b$ & $1.26 b c$ & $29.40 \mathrm{ab}$ & $16.99 \mathrm{ab}$ & $40.71 b$ & $30.26 a$ & $21.07 \mathrm{a}$ & $8.74 b$ & $2.90 \mathrm{de}$ \\
\hline $\mathrm{T}_{4}$ & $4.43 \mathrm{a}$ & $0.84 \mathrm{ab}$ & $1.39 \mathrm{a}$ & $32.53 \mathrm{ab}$ & $19.96 \mathrm{a}$ & $44.69 \mathrm{a}$ & $21.05 b c$ & $9.30 \mathrm{c}$ & $8.98 b$ & $4.83 \mathrm{~cd}$ \\
\hline $\mathrm{T}_{5}$ & $4.17 b$ & $0.85 b$ & $1.28 \mathrm{~b}$ & $33.35 \mathrm{a}$ & $14.68 b c$ & $40.77 \mathrm{~b}$ & $18.70 \mathrm{c}$ & $9.50 \mathrm{c}$ & $4.29 c$ & $9.10 \mathrm{a}$ \\
\hline $\mathrm{T}_{6}$ & $4.11 \mathrm{~b}$ & $0.88 \mathrm{a}$ & $1.17 \mathrm{c}$ & $32.59 \mathrm{ab}$ & $16.31 b c$ & $41.07 b$ & $21.12 b$ & $16.27 \mathrm{ab}$ & $4.27 \mathrm{c}$ & $5.30 \mathrm{bc}$ \\
\hline $\mathrm{CV}(\%)$ & $5.32 \%$ & $3.64 \%$ & $4.03 \%$ & $9.94 \%$ & $5.92 \%$ & $2.52 \%$ & $9.29 \%$ & $10.62 \%$ & $11.78 \%$ & $23.03 \%$ \\
\hline $\operatorname{LSD}_{(0.05)}$ & 0.41 & 0.06 & 0.10 & 5.60 & 3.03 & 1.92 & 4.14 & 2.38 & 2.18 & 2.18 \\
\hline
\end{tabular}

Means followed by same letter significantly different at $1 \%$ or $5 \%$ level of significance.

\section{CONCLUSION}

Effect of various sawdust substrates on the nutritional composition of Pleurotuus florida was analyzed. Amongst all the treatment the highest phosphorous was obtained from $\mathbf{T}_{\mathbf{1}}$ substrate. The highest amount of lipid, protein, ash, moisture and molybdenum were obtained from $\mathbf{T}_{2}$ sawdust substrate. The highest amount of cobalt and zinc were obtained from $\mathbf{T}_{\mathbf{3}}$ sawdust substrate. The highest amounts of carbohydrate, dry matter, nitrogen, potassium, magnesium and iron were obtained from $\mathbf{T}_{\mathbf{4}}$ sawdust substrate. The highest amount of crude fiber, calcium and selenium were obtained from $\mathbf{T}_{\mathbf{5}}$ substrate. The lowest amount of lipid was found from $\mathbf{T}_{6}$ substrate. Therefore observing the nutritional composition it is apparent that $\mathbf{T}_{\mathbf{4}}$ substrate is the best amongst all the applied treatment for locally producing popular Pleurotus florida mushroom variety in Bangladesh. In pharmaceutical aspects,
Pleurotus florida mushroom has been proven to be highly significant in the context of our country's economy and providing nutrition to the people as well. As the inclusion of whole mushrooms into the diet may have efficacy as potential dietary supplements.

\section{ACKNOWLEDGEMENT}

National Mushroom Development and Extension Center Laboratory Savar, Dhaka, Bangladesh is gratefully acknowledged for their kind cooperation regarding the supply the fruiting body of oyster mushroom and recorded the atomic absorption data.

\section{REFERENCES}

1. Alexopoulos, C.J., Mims, C.W. and Blackwell, M. 1996. Introductory Mycology. John Wiley \& Sons, Inc, New York. 
2. Kong, W.S. 2004. Descriptions of commercially important Pleurotus species. In: Mushroom world (Ed.). Oyster mushroom cultivation. Part II. Oyster mushrooms. Seoul: Heineart Incorporation, pp. 54-61.

3. Rajarathnam, S., Shashirekha, M.N. and Rashmi. 2003. Biochemical changes associated with mushroom browning in Agaricus bisporus (Lange) Imbach and Pleurotus florida (Block and Tsao): Commercial implications. J. Sci. Food Agri. 83, 1531-1537.

4. Shah, Z.A., Ashraf, M. and Ishtiq, C. 2004. Comparative study on cultivation and yield performance of oyster mushroom (Pleurotus ostreatus) on different substrates (Wheat straw, Leaves, saw dust). Pak. J. Nutri. 3, 158-160.

5. Mane, V.P., Patil, S.S., Syed, A.A. and Baig, M.M.V. 2007. Bioconversion of low quality lignocellulosic agricultural waste into edible protein by Pleurotus sajor-caju (Fr.) Singer. J. Zhejiang Univ. Sci. 8, 745-751.

6. Lourdes, A.T., Arvin, S.M.A. and Jerremy, B.R. 2008. Agronomic responses of oyster mushroom (Pleurotus ostreatus) on different agricultural wastes as substrates. Retrievedfrom: $\quad$ http://region1.dost.gov.ph/IPSF\% 20compilations/pdf\%20files/agronomic \% 20 responses.pdf (Accessed on: November 8, 2008).

7. Jonathan, S.G. and Esho, E.O. 2010. Fungi and Aflatoxin detection in two oyster mushrooms Pleurotus ostreatus \& Pleurotus pulmonarius from Nigeria. Electronic J. Environ. Agri. Food Chem. (EJEAFche). 9, 1722-1730.

8. Godfrey, E.Z., Siti, M.K. and Judith, Z.P. 2010. Effects of temperature and hydrogen peroxide on mycelial growth of eight Pleurotus strains. Scientia Horticulture 125, 95-102.

9. Chang, S.T. 2006. Development of the culinary-medicinal mushrooms industry in China: past, present and future. Int. $J$. Medi. Mushroom. 8, 1-17.

10. Akinmusire, O.O., Omomowo, I.O. and Oguntoye, S.I. 2011. Cultivation performance of Pleurotus Pulmonarius in Maiduguri, North Eastern Nigeria, using wood chippings and rice straw waste. Advances in Environmental Biology 5, 2091-2094.

11. Jonathan, S.G., Okorie, A.N., Garuba, E.O. and Babayemi, O.J. 2012. Bioconversion of sorghum stalk and rice straw into value added ruminant feed using Pleurotus pulmonarius. Nature and Science. 10, 10-16.

12. Chang, S.T. and Miles, P.G. 1989. Edible Mushrooms and Their Cultivation. CRC Press, Boca Raton, pp.1-38.

13. Chang, S.T. and Wasser, S.P. 2012. The role of culinarymedicinal mushrooms on human welfare with a pyramid model for human health. Int. J. Medi. Mush. 14, 95-134.

14. Chandy, K.T. 1997. Oyster Mushroom Cultivation. Indian Social Institute, New Delhi, p. 21.

15. Finimundy, T. C., Gambato, G. and Fontana, R. 2013. Aqueous extracts of Lentinula edodes and Pleurotus sajor- caju exhibit high antioxidant capability and promising in vitro antitumor activity. Nutrition Research. 33, 76-84.

16. Yu, S., Weaver, V., Martin, K. and Cantorna, M.T. 2009. The effects of whole mushrooms during inflammation. $B M C$ Immunology. 10, 12.

17. Zhang, L., Fan, C., Liu, S., Zang, Z. and Jiao, L. 2011. Chemical composition and antitumor activity of polysaccharide from Inonotus obliquus. J. Medi. Plants Res. 5, 1251-1260.

18. Patel, S. and Goyal, A. 2012. Recent developments in mushrooms as anticancer therapeutics: a review. Biotech. 2, $1-15$.

19. Chen, J. and Seviour, R. 2007. Medicinal importance of

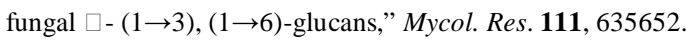

20. Heleno, S.A., Barros, L., Sousa, M.J., Martins, A. and Ferreira, I.C.F.R. 2010. Tocopherols composition of Portuguese wild mushrooms with antioxidant capacity. Food Chem. 119, 1443-1450.

21. Mattila, P., Köonköo, K. and Eurola, M. 2001. Contents of vitamins, mineral elements, and some phenolic compounds in cultivated mushrooms. J. Agri. Food Chem. 49, 2343-2348.

22. Alam, N., Khan, A., Hossain, M.S., Amin, S.M.R. and Khan, L.A. 2007. Nutritional Analysis of dietary Mushroom Pleurotus florida Eger and Pleurotus sajorcaj Fr.) Singer. Bangladesh J. Mushroom. 1, 1-7.

23. Purkayastha, R.P., and Nayak, D. 1981. Analysis of Protein patterns of an Edible mushroom by Gel Electrophoresis and its amino acid composition. J. Food Sci. Tech. 18, 89-91.

24. Beelman, R.B., Royse, D. and Chikthimmah, N. 2003. Bioactive components in button mushroom Agaricus bisporus (J. Lge) Imbach (Agaricomycetideae) of nutritional, medicinal, or biological importance (Review). Int. J. Med. Mushroom. 5, 321-327.

25. Manzi, P., Gambelli, L., Marconi, S., Vivanti, V. and Pizzoferrato, L. 1999. Nutrients in edible mushrooms: An inter-species comparative study. Food Chem. 6, 477-482.

26. Kurtzman, R.H. Jr. 2005. A review mushrooms: sources for modern western medicine. Micologia Aplicada International. 17, 21-33.

27. Çağlarırmak, N. 2007. The nutrients of exotic mushrooms (Lentinula edodes and Pleurotus species) and an estimated approach to the volatile compounds. Food Chemistry, 105, 1188-1194.

28. Banik, S. and Nandi, R. 2004. Effect of supplementation of rice straw with biogas residual slurry manure on the yield, protein and mineral contents of oyster mushroom. Industrial Crops and Products. 20, 311-319.

29. Zadrazil, F. and Brunnert, F. 1981. Investigation of physical parameters important for the solid state fermentation of straw by white rot fungi. Eur. J. Appl. Microbiol. Biotech. 11, 183188. 
30. Platt, M.W., Hadar, Y. and Chet, I. 1984. Fungal activities. Microbiol. Biotech. 20, 150-154.

31. Jandaik, C.L. and Goyal, S.P. 1995. Farm and farming of oyster mushroom (Pleurotus spp.). Singh and Chaube (editors), Mushroom Production Technology. G. B. Pant Univ. Agri. and Tech., Pantnagar, India, pp. 72-78.

32. Baysal, E., Peker, H., Kemal, M. and Temiz, A. 2003. Cultivation of oyster mushroom on waster paper with some added supplementary materials, Bioresour. Technol. 89, 95-97.

33. Mau, J.L., Lin, H.C. and Chen, C.C. 2002. Antioxidant properties of several medicinal mushrooms. J. Agri. Food Chem. 50, 6072-6077.

34. Isikhuemhen, O.S., Nemd, F. and Vilgahus, R. 2000. Cultivation studies in wild and hybrid straim of Pleurotus tuberregium (Fr) Sing on wheat straw substrate. World J. Microbiol. Biotech. 16, 431- 435.

35. Okhuoya, J.A., Akpaja, E.O. and Abbot, O. 2005. Cultivation of Lentinus squarrosulus (mont) singer on sawdust of selected tropical tree species. Int. J. Med. Mushroom. 7, 213218.

36. Hadwan, H.A., Al-Jaboury, M.H. and Hassan, A.O. 1997. Suitability of different substrates and amendments on the cultivation of oyster mushroom Collection of Thesis Materials. S \& T, Development, Environment and Resources. Proc. 96 FUZHOU international, Symposium on the development of juncau industry, pp. 215-221.

37. Kent, N.L. and Evers, A.D. 1994. Technology of Cereals. 4th Edition, Pergmon Press, Oxford, pp. 276-301.

38. Bhattacharjya, D.K., Paul, R.K., Miah, M.N., Ahmed, K.U. 2014. Effect of Different Saw Dust Substrates on the Growth and Yield of Oyster Mushroom (Pleurotus ostreatus). IOSR J. Agri. Veteri. Sci. (IOSR-JAVS). 7, 38-46. e-ISSN: 23192380, p-ISSN: 2319-2372.

39. Amin, S.M., Rahman, M.M., Hossain, M.M., Haque, M.M. and Sarker, N.C. 2007. Effect of different substrates on the growth and yield of five selected oyster mushrooms. Bangladesh J. Mushroom 1, 21-25.

40. Pati, S.S., Ahmed, S.A., Telang, S.M. and Bai, M.M.V. 2010. The nutritional value of Pleurotus Ostreatus (JACQ:FR.) KUMM cultivated on different lignocellulosic agrowastes. Innovative Romanian Food Biotechnology 7, 66-76.

41. Raghuramulu, N., Madhavan, N.K. and Kalyanasundaram, S. 2003. A Manual of Laboratory Techniques. National
Institute of Nutrition, Indian Council of Medical Reasearch, Hyderabad-500007, India, pp. 56-58.

42. Sarker, N.C., Hossain, M.M., Sultana, N., Mian, I.H., Karim, A.J.M. and Amin, S.M.R. 2007. Impact of different substrates on nutrient content of Pleurotus ostreatus(Jacquin ex Fr.) Kummer. Bangladesh J. Mushroom 1, 51-56.

43. Khan, N.A., Ajmal, M., Nicklin, J., Aslam, S. and Ali, M.A. 2013. Nutational value of pleurotus (flabellatus) DJAMOR(R-22) cultivated on sawdusts of different woods. Pak. J. Bot. 45, 1105-1108.

44. Ahmed, M., Abdullah, N., Ahmed, K.U. and Bhuyan, M.H.M.B. 2013. Yield and nutritional composition of oyster mushroom strains newly introduced in Bangladesh. Pesq. agropec. Bras. Brasília. 48, 197-202.

45. James, C.S. 1995. Analytical Chemistry of Foods (1st ed.). Chapman and Hall, New York Cultivation of Edible and Medicinal Fungi, Penn State University, Pennsylvania.

46. Chang, S.T. and Buswell, J.A. (2003). Mushrooms-A prominent source of nutriceuticals for the 21 st Century. Curr. Topics in Neutraceutical Res. 1, 257-280.

47. Yamakawa, T. 1992. Laboratory methods for soil science and plant nutrition. JICA-IPSA Project Publication, IPSA, Gazipur, Bangladesh, pp.1-14.

48. Gomez, K.A. and Gomez, A.A. 1984. Statistical procedures for agricultural research. John Wiley \& Sons, Inc. New York.

49. Moni, K.H., Ramabardan, R. and Eswaran, A. 2004. Studies on some physiological, cultural and post-harvest aspects of Oyster mushroom Pleurotus ostreatus (Berk). Trop: Agri. Res. 12, 360-374.

50. Chang, S.T., Lau, O.W. and Cho, K.Y. 1981. The cultivation and nutritional value of Pleurotus sajor-caju. Eur. J. Appl. Microbiol. Biotech. 12, 58-62. DOI: 10.1007/BF00508120.

51. Zhang-Rui, H., Jin, H., Fadel, L.-X. and Li-XJ, J.G. 1998. Oyster mushroom cultivation with rice and wheat straw. Biores. Tech. 82, 277-284.

52. Khlood, A. and Ahmad, A. 2005. Production of oyster mushroom (Pleurotus ostreatus) on olive cake agro waste. Dirasat Agri. Sci. 32, 64-70. 